\title{
Rare evidence of pre-Gondwana intraplate magmatism within Indian continent: Constrained from U-Pb geochronology and geochemistry of gabbro from Siang window, Eastern Himalaya, Northeast India.

\author{
GOVIND OINAM AND KRISHNAKANTA SINGH
} \\ ATHOKPAM
}

Wadia Institute of Himalayan Geology

Presenting Author: govindoinam@gmail.com

\begin{abstract}
Abor volcanics $(\sim 135 \mathrm{Ma})$ in eastern Himalaya have been considered as significant evidence of Gondawana breakup and outpour of intraplate volcanism at the edge of Indian plate. However, records before this event is rarely documented in the region. We report here new LA-MC-ICPMS U-Pb zircon age and geochemical data for gabbro intrusives from Siang Window, Eastern Himalaya to scrutinise their petrogenesis and tectonomagmatic evolution. These gabbros are sub-alkaline having low $\mathrm{SiO}_{2}$ (49.39-54.95 wt. \%), $\mathrm{MgO}$ (5.46-7.40 wt. \%), $\mathrm{TiO}_{2}$ (0.97-1.93 wt. \%) and $\mathrm{Fe}_{2} \mathrm{O}_{3}$ (7.09-12.7 wt. \%) contents, typical of tholeiitic series. Chondrite normalized REE patterns display enrichment of LREE with slightly positive Eu anomaly. Enrichment in LILE and HFSE is also observed at equal rate to E-MORB composition. Partial melting modelling suggests their magma derivation due to $12-28 \%$ partial melting of a spinel+garnet peridotite source. Although they show equal geochemical signatures, calculated U-Pb zircon age shows two different ages of $567.66 \pm 2.09 \mathrm{Ma}$ and $521.50 \pm 2.53 \mathrm{Ma}$. It implies that there were two pulses of intraplate magmatism at $\sim 567$ and $\sim 521 \mathrm{Ma}$, which are inconsistent with the temporal distribution of Paleozoic magmatism in the Siang window of the Eastern Himalayas. We conclude that prior to the formation of Gondwana super-continent and its tearing apart during cretaceous, Indian continental margin had come across with multiple intraplate magmatism, probably as a consequence of long-lasting Pan-African orogenic cycle of the late Neoproterozoic to early Cambrian.
\end{abstract}

